\title{
PERFORMANCE OF NANO-FILTRATION AND REVERSE OSMOSIS PROCESSES FOR WASTEWATER TREATMENT
}

\author{
OCENA ZMOGLJIVOSTI POSTOPKOV NANOFILTRACIJE IN \\ POVRATNE OSMOZE PRI OBDELAVI ODPADNE VODE
}

\author{
Saad Al-Jlil \\ National Center for Membrane Technology (NCMT), King Abdulaziz City for Science and Technology (KACST), \\ P. O. Box 6086 Riyadh, Saudi Arabia \\ saljlil@kacst.edu.sa
}

Prejem rokopisa - received: 2015-08-09; sprejem za objavo - accepted for publication: 2016-06-30

doi:10.17222/mit.2015.250

\begin{abstract}
This study was carried out to evaluate the performance of nano-filtration (NF) and reverse osmosis (RO) technology for reducing the total salt concentration from waste water. The nano-filtration proved very effective in removing the polyvalent cations and anions, such as $\mathrm{SO}_{4}^{-}$, whereas the removal efficiency was $97.22 \%$. It is well known that a $\mathrm{RO}$ water-treatment process removes all the cations and anions from waste water or brine or sea water, especially removing the monovalent ions such as $\mathrm{Cl}^{-}$where the removal efficiency was $94.4 \%$. The performance efficiency of RO and NF water-treatment processes declined significantly during the first 3 years of operation due to fouling and biofouling of the membrane. The research findings provided a concrete clue for the important issue of water treatment as an alternative to existing water use methods on a cost-effective basis. The research also highlighted the potential to replace the NF and RO membranes used in these two water-treatment techniques.
\end{abstract}

Keywords: desalination of waste water, reverse osmosis, nano-filtration

Izvedena je bila študija ocene zmogljivosti tehnologije nanofiltracije (angl. NF) in povratne osmoze (angl. RO) za zmanjšanje skupne vsebnosti soli v odpadni vodi. Nanofiltracija je zelo učinkovita pri odpravljanju polivalentnih kationov in anionov, kot so $\mathrm{SO}_{4}^{-}$, kjer je bila učinkovitost odstranitve $97,22 \%$. Dobro je poznano, da RO postopek obdelave vode odstrani vse katione in anione iz odpadne vode, slanice ali morske vode, še posebno monovalentni $\mathrm{Cl}^{-}$, kjer je bila učinkovitost odstranitve $94,4 \%$. Zmogljivost RO in NF procesov pri obdelavi vode se občutno zmanjša med prvim 3-letnim obratovanjem zaradi mašenja in biološkega nalaganja na membrane. Ugotovitve raziskave omogočajo konkreten namig za pomembno vprašanje obdelave vode, kot cenovno učinkovita alternativa sedanjim metodam. Raziskava je pokazala tudi možnost za zamenjavo NF in RO membran, ki se jih uporablja $v$ teh dveh načinih obdelave vode.

Ključne besede: razsoljevanje odpadne vode, povratna osmoza, nanofiltracija

\section{INTRODUCTION}

Water uses are manifold, ranging from domestic, agriculture to industries. Among these, the chemical industry uses water as a coolant and to generate steam from boilers for use in different industrial processes for the production of different types of products. In boilers, water evaporates continuously and the dissolved salts precipitate after reaching the saturation stage at equilibrium, thus forming a hard scale that deposits on the inner walls of the boiler. There are several disadvantages of these deposits. Among them, the most important is corrosion, which decreases the efficiency of the boiler unit through the clogging of pipes, valves and condensers, decreases the heat-transfer rate, causes the excessive use of fuel and a danger of explosion. Therefore, wastewater treatment is important for the safe operation of boilers. Among the traditional methods of water softening, the addition of lime-soda is one process. But this process has some disadvantages i.e., it leaves more sodium chloride as residue in the raw water and the need for reaction tanks equipped with mechanical stirrers in addition of course to the main chemicals used by the process and the coagulant to facilitate filtration of the formed precipitates.

Presently, among the various techniques for softening high-hardness waters, membrane separation is a new approach. The membrane-separation processes have the unique advantage of not requiring energy to affect phase changes compared to distillation or crystallization. Hence, it is an economically attractive alternative as compared to costly methods due to low energy requirements.

The objective of this work was to investigate the possibility of using reverse osmosis and nano-filtration processes to improve the water quality by removing the major cations and anions, such as calcium, magnesium and chloride, from wastewater. We also wanted to determine the decline in the performance of RO and NF processes due to membrane fouling.

\section{REVIEW OF LITERATURE}

\subsection{RO - Technology application}

Membrane technology is playing an important role in the reclamation of municipal wastewater. In particular, high-quality reclaimed wastewater can be used by 
industrial customers. Currently, many large-scale commercial membrane plants are in use for the treatment of municipal wastewater. These plants include the $270,000 \mathrm{~m}^{3} /$ day plant in Orange County, California and the $380,000 \mathrm{~m}^{3} /$ day plant for Sulayabia, Kuwait. ${ }^{1}$

A typical municipal wastewater treatment process consists of primary, secondary and tertiary treatments. When tertiary effluent from a conventional treatment process is supplied to a RO system, it encounters all forms of fouling, i.e., colloidal, biological, scaling and organic fouling. The coatings of foulant will impede the water transport through the membranes, thus resulting in short membrane life and increased operational cost.

Since the development of practical cellulose acetate membranes in the early 1960s and the subsequent development of thin-film, composite membranes, the use of reverse osmosis technology expanded to include not only the traditional desalination process but also a wide range of wastewater treatment applications. Several advantages of the RO process that make it particularly attractive for dilute aqueous wastewater treatment have been widely advocated by many investigators. ${ }^{2-4}$ The applications reported for RO processes include the treatment of organic-containing wastewater, wastewater from electroplating and metal finishing, pulp and paper, mining and petrochemical, textile, and food processing industries, radioactive wastewater, municipal wastewater, and contaminated groundwater. ${ }^{2,4,5}$

\subsection{Contaminated drinking water}

Reverse osmosis processes can simultaneously remove hardness, color, many kinds of bacteria and viruses, and organic contaminants such as agricultural chemicals and trihalomethane precursors. T. Eisenberg and E. Middle Brooks ${ }^{6}$ reviewed the RO treatment of drinking-water sources, and they indicated that RO can successfully remove a wide variety of contaminants. E. Chian et al. ${ }^{7}$ studied several agricultural chemicals contaminating water supplies and found their removal was good by adsorption on the membranes. H. Odegaard and S. Koottatep ${ }^{8}$ reported that humic and fulvic materials, which are THM precursors, were largely removed by RO membranes. T. Clair et al. ${ }^{9}$ found the excellent removal $(>95 \%)$ of dissolved organic carbon from natural waters using FT30 membranes. T. Sorg et al. ${ }^{10}$ showed that the RO system can effectively remove radium from contaminated water. J. Baier et al. ${ }^{11}$ reported the removal of several agricultural chemicals from groundwater from $0 \%$ to $>94 \%$ using different membranes. J. Taylor et al. ${ }^{12}$ found that RO membranes could be used to remove $96 \%$ of DOC, $97 \%$ of color, $97 \%$ of trihalomethane formation potential (THMFP), and $96 \%$ of total hardness. L. Tan and R. Sudak ${ }^{13}$ examined several RO membranes and found that all were capable of acceptably removing color from groundwater, even over long operating periods.

\section{3 Municipal wastewater}

Reverse osmosis (RO) can remove dissolved solids from municipal wastewaters, which cannot be removed by biological or other conventional water-treatment processes. However, extensive pretreatment and periodic cleaning are usually needed to maintain acceptable membrane water fluxes. Early studies ${ }^{14,15}$ showed that the high removal of TDS and the moderate removal of organics can be achieved. H. Tsuge and R. Mori ${ }^{16}$ showed that tubular membranes (with a substantial pretreatment system) can remove both the inorganic and organic pollutants from municipal secondary effluent and produce water that meets drinking-water standards. Previously, N. Richardson and D. Argo ${ }^{17}$, P. Allen and G. Elser ${ }^{18}$ and I. Nusbaum and D. Argo ${ }^{19}$ discussed municipal wastewater treatment at a large scale plant (Water Factory 21, Orange County, California). The feed water to the plant consisted of secondary effluent, and the process was composed of a variety of treatment systems, including RO membranes (several different types) with a 5 MGD capacity. The process reduced TDS and organics to levels that allowed the effluent to be injected into groundwater aquifers used for water supplies.

E. Cséfalvay et al. ${ }^{20}$ stated that membrane separations are gaining increasing interest in wastewater treatment due to their efficiency. Nano-filtration and reverse-osmosis membranes were tested under different conditions to reduce the chemical oxygen demands (COD) of wastewaters. However, none of the membranes decreased the COD to the release limit in one step. Gholami et al. found that the range of rejection was $73.52 \%$ to $99.36 \%$ and $75.1 \%$ to $98.8 \%$, for amoxicillin and ampicillin, respectively. Also, the application of the $\mathrm{RO}$ membrane was recommended for the removal of selected antibiotics up to $95 \%$ from synthetic waste effluent. ${ }^{21}$ In addition pressure-driven membrane processes, particularly nanofiltration (NF) and reverse osmosis (RO) have also been gaining attention in the past decade and their application in drinking-water treatment has been the focus of many researchers. ${ }^{22}$

\subsection{Nano-filtration applications}

Recently, nano-filtration membranes, having high water fluxes at low pressures, were developed as new applications in wastewater treatment. These membranes also reject organic compounds with molecular weights above 200 to 500 . These properties have made possible some interesting new applications in wastewater treatment, such as selective separation and the recovery of pollutants that have charge differences, the separation of hazardous organics from monovalent salt solutions, and membrane softening to reduce hardness and trihalomethane precursors in drinking-water sources. ${ }^{23,} 24$

\subsection{Contaminated drinking-water supplies}

Nano-filtration membranes have attracted a great deal of attention for use in water softening and the removal of 
various contaminants from drinking-water sources. Nano-filtration (NF) processes can reduce or remove TDS, hardness, color, agricultural chemicals, and highmolecular-weight humic and fulvic materials (which can form trihalomethanes when chlorinated). In addition, NF membranes typically have much higher water fluxes at low pressures than traditional RO membranes used for this application. W. Conlon ${ }^{25}$ reported that FilmTec NF50 membranes can effectively remove color (96\%) and TOC $(84 \%)$, reduce hardness and TDS, and lower trihalomethane formation potential (THMFP) to below regulatory levels. P. Eriksson ${ }^{23}$ and J. Cadotte et al. ${ }^{24}$ also indicated that NF membranes (such as FilmTec NF40, NF50, and NF70) can be used to reduce TDS, hardness, color, and organics. B. Watson and C. Hornburg ${ }^{26}$, and W. Conlon et al. ${ }^{27}$ have also identified NF as an emerging technology for compliance with THM regulations and for the control of TDS, TOC, color, and THM precursors. P. Lange et al. ${ }^{28}$ also suggested that NF treatment would be a reliable method of meeting existing and future THM limits compared to chemical treatment alternatives. G. Amy et al. ${ }^{29}$ used NF70 membranes to remove dissolved organic matter from both groundwater (recharged from secondary effluent) and surface water in order to reduce THM precursors. They found that the process was effective in reducing the organics as well as the conductivity in both water sources. S. Duranceau et al. ${ }^{30}$ also reported on the use of NF70 membrane separation for several agricultural chemicals spiked in groundwater. Ethylene dibromide and dibromochloropropane removals averaged $0 \%$ and 32 $\%$, respectively, while the remaining organics (chlordane, heptachlor, methoxychlor, and alachlor) were $100 \%$ removed. Rejections of TDS were $85 \%$ and THMFP were $95 \%$. However, it was also indicated that some of the organics adsorbed on the membrane.

\subsection{Wastewater}

Nano-filtration is also used to remove both the organics and inorganics from different wastewaters. A. Bindoff et al. ${ }^{31}$ reported that using NF membranes, the color removal was $>98 \%$ at water recoveries up to $95 \%$, while the in-organics were poorly rejected. K. Ikeda et al. ${ }^{32}$ indicated NF could give high separations of color-causing compounds such as lignin sulphonates in paper pulping wastewaters. M. Afonso et al. ${ }^{33}$ found NF removal $(>95 \%)$ of chlorinated organic compounds from alkaline pulp and paper bleaching effluents with high water fluxes. M. Simpson et al. ${ }^{34}$ reported the use of NF membranes to remove hardness and organics in textile mill effluents. S. Gaeta and U. Fedele ${ }^{35}$ also indicated high water recoveries (up to $90 \%$ ) from textile dye house effluent could be achieved with NF membranes. M. Perry and C. Linder ${ }^{36}$ discussed the recovery of lowmolecular-weight dyes from high salt concentration effluent. K. Ikeda et al. ${ }^{32}$ and J. Cadotte et al. ${ }^{24}$ reported the use of NF membranes in the treatment of food-pro- cessing wastewaters. Some specific uses included the desalting of whey and the reduction of high BOD and nitrate levels in potato processing waters (Anonymous, 1988b). D. Bhattacharyya et al. ${ }^{37}$ used NF40 membranes to selectively separate mixtures of cadmium and nickel. M. Williams et al. ${ }^{38}$ examined NF40 membranes with and without pretreatment by feed preozonation to study the removal of various chlorophenols and chloroethanes. TOC rejections up to $90 \%$ were possible with ozonation pretreatment. R. Rautenbach and A. Gröschl ${ }^{39}$ discussed the separation results of several organics (ranging from methanol to ethylene glycol) by various NF membranes. M. Chu et al. ${ }^{40}$ detailed the use of NF in a process for treating uranium wastewater; NF40 uranium rejections were $97 \%$ to $99.9 \%$. C. Dyke and Bartels ${ }^{41}$ discussed the use of NF membranes to replace activated carbon filters for the removal of organics from off-shore produced water containing residual oils. The produced waters contained $\sim 1000 \mathrm{mg} \mathrm{L}^{-1}$ soluble organics (mostly carboxylic acids) and high inorganic concentrations $\left(\sim 15,000 \mathrm{mg} \mathrm{L}^{-1} \mathrm{Na}^{+}\right.$and $\sim 25,000 \mathrm{mg} \mathrm{L}^{-1} \mathrm{Cl}^{-}$as well as other dissolved ions). Organic rejections were suitable to meet discharge standards, while inorganic rejections were low $(<20 \%)$, allowing operation at low pressures.

Andrade et al. observed that the MBR efficiently removed the organic matter and color of the feed effluent followed by nano-filtration as a polishing step for the removal of high contents of solids. ${ }^{42}$ While the membrane separation systems and the combination of these systems with other technologies, such as membrane bioreactors (MBR), are the most promising treatment technologies for effluent reuse. ${ }^{43}$ Also, studies show that $\mathrm{NF}$ is an efficient treatment system for secondary or tertiary effluents aiming at the generation of water for industrial, agricultural, or indirect potable reuse. ${ }^{44,45}$

\section{MATERIALS AND METHODS}

The experiment was carried at the Wastewater Treatment Plant (WTP), National Center for Water technology (NCWT), King Abdulaziz City for Science and Technology (KACST) during 2012-2013.

\subsection{Analysis of wastewater samples}

The water samples were analyzed for $\mathrm{pH}$, cations and anions. Cations and anions such as chloride, sulphate were determined by using Dionex 300 Ion chromatography. The requirements for this analysis are Dionex ion chromatography with column As-14 (4mm), guard column AS-12, suppressor-ASR-1, fluent mixture of carbonate and bicarbonate, deionized water and nitrogen gas. The total dissolved solids (TDS) were estimated using Oven Heraeus Instruments. The $\mathrm{pH}$ was measured by using Hach HQ D40. 
S. AL-JLIL: PERFORMANCE OF NANO-FILTRATION AND REVERSE OSMOSIS PROCESSES ...

\subsection{Experimental set-up}

\subsubsection{Advanced waste water treatment units (AWWTU)}

The AWWTU at KACST consists of two parts representing two different water treatment technologies such as a Reverse Osmosis Unit (RO-Unit) and Nano-filtration $(\mathrm{NF})$.

\subsubsection{RO-Unit}

The pre-treated water from the biological unit is desalinized using the RO-technology. Its water production capacity is $0.12 \mathrm{~m}^{3} / \mathrm{h}$ (Figure $\left.\mathbf{1}\right)$.

\subsubsection{NF-Unit}

The pre-treated water from the biological unit is desalinized by applying NF technology. Its water production capacity is $0.12 \mathrm{~m}^{3} / \mathrm{h}$ (Figure 2).

\section{RESULTS AND DISCUSSION}

The results of the RO and NF wastewater treatment technologies containing cations and anions are presented in Figure 3. Only moderate rejection was observed for the monovalent species, as expected with NF. However, the rejection of polyvalent cations and anions was high.

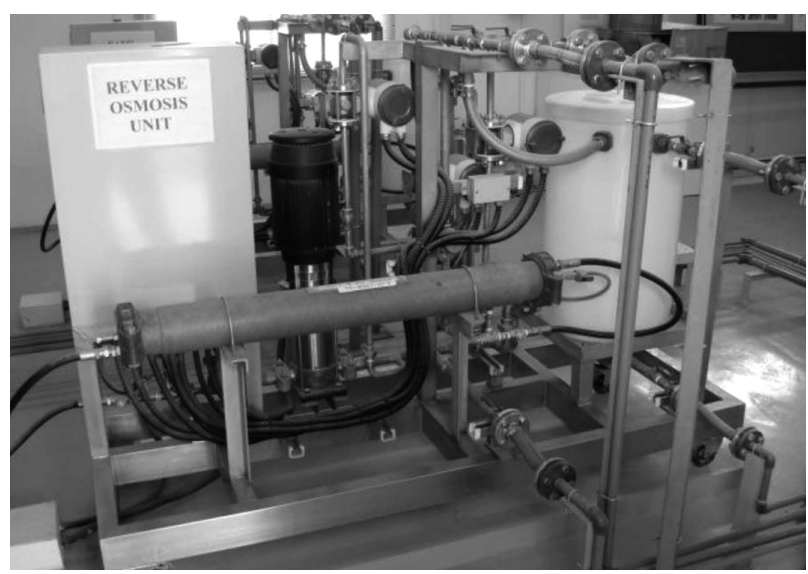

Figure 1: Layout of reverse osmosis (RO) unit

Slika 1: Postavitev naprave za reverzibilno osmozo (RO)

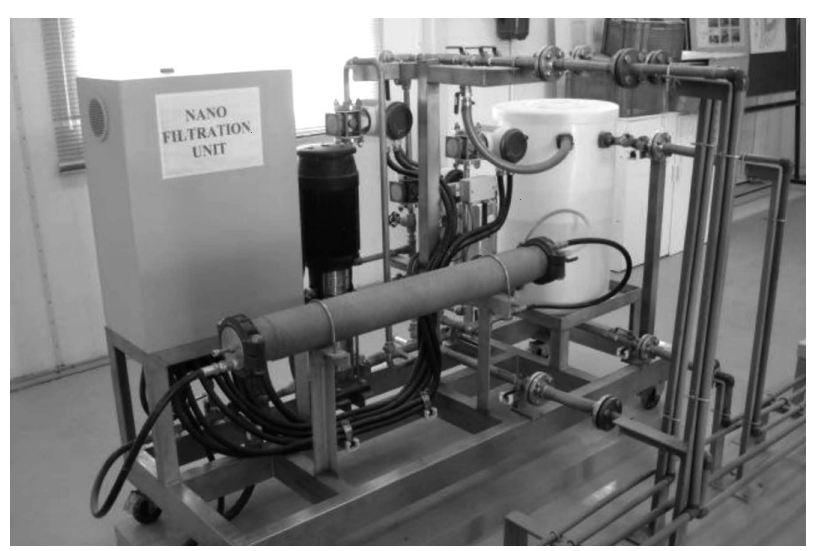

Figure 2: Layout of nano-filtration unit

Slika 2: Postavitev nanofiltracijske naprave

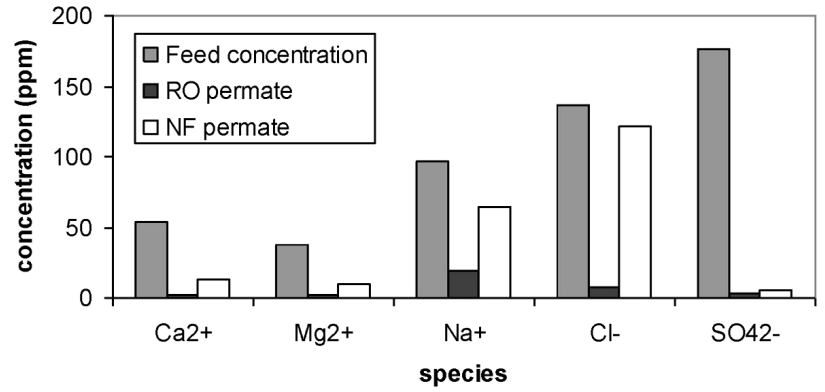

Figure 3: Comparison of the performance of new RO and NF membranes

Slika 3: Primerjava zmogljivosti novih RO in NF membran

On the other hand, strong rejection was observed for monovalent cations and anions by $\mathrm{RO} .{ }^{46}$ The percentage rejection of species ions (rej. \%) was calculated as follows in Equation (1):

$$
\text { rej } \%=\frac{a-b}{a} \times 100
$$

$a$ - concentration of species in the feed,

$b$ - concentration of species in the permate.

The data in Figure 4 shows the results of the advanced treatment RO and NF of waste water containing cations and anions using old RO and NF membranes (worked for 3 years). It was found that the rejection of the cations and anions decreased for monovalent species. This behavior is expected with old membranes. Also, modest rejection was observed for polyvalent cations and anions. On the other hand, moderate rejection was observed for monovalent cations and anions by RO due to membrane fouling and biofouling. This reason is definitely right, because the wastewater has different types of bacteria and pathogens and organic material. The organic material adsorbed onto the membrane surface and increased the fouling problem.

Figure 5 shows the performance of $\mathrm{NF}$ and $\mathrm{RO}$ for the rejection of TDS. In general, the TDS rejection decreases with an increase in the feed concentration due to increased concentration polarization at the membrane solution interface. ${ }^{47}$ It was observed that TDS rejection was less by NF than RO membrane. This could be attributed to the monovalent ions such as $\mathrm{Na}^{+}$, which

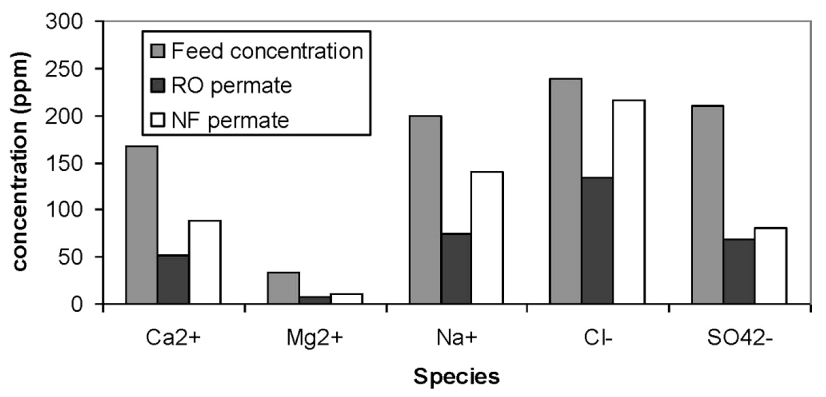

Figure 4: Comparison of the performance of old RO and NF membranes

Slika 4: Primerjava zmogljivosti starih RO in NF membran 
S. AL-JLIL: PERFORMANCE OF NANO-FILTRATION AND REVERSE OSMOSIS PROCESSES ...

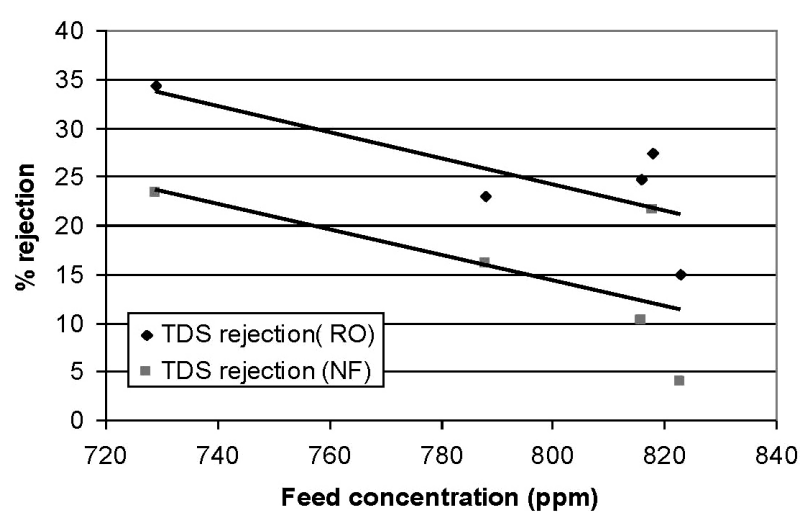

Figure 5: Percentage rejection of TDS versus feed concentration for $\mathrm{RO}$ and NF membranes

Slika 5: Odstotek zavrnitev TDS v odvisnosti od vstopne koncentracije pri RO- in NF-membranah

represents the main component in the feed water; therefore, the ability of NF in rejection of the monovalent ions is weak.

Figure 6 shows the performance of the NF and RO membranes for the rejection of TDS at the same $\mathrm{pH}$ of feed water. The percentage rejection of the $\mathrm{Na}^{+}$ion by RO membrane was higher than the NF membrane. This could be attributed to the fact that the rejection of monovalent ions such as $\mathrm{Na}^{+}$by $\mathrm{NF}$ is weak. ${ }^{42,43}$ In addition, the $\mathrm{pH}$ did not affect the membrane rejection when the polyamide membrane $\mathrm{pH}$ operating range is $4-11$.

Figure 7 shows the results of RO for waste water treatment containing cations and anions using the old RO and new RO membranes. The old membrane was 3 years old. It was found that the percent rejection decreased for all the ion species. For example, the percent rejection of $\mathrm{Cl}^{-}$ion was $94.4 \%$ using the new membranes and the membrane percent rejection was 43.9 after three years. This would mean that the membrane performance declined due to fouling and biofouling. The study results agree with those of Gholami et al., and Sahar et al. who reported the significant rejection of pollutants from waste effluents..$^{21,22}$

Figure 8 shows the results of NF for wastewater treatment containing cations and anions using the old NF and new NF membranes. The old membrane worked for

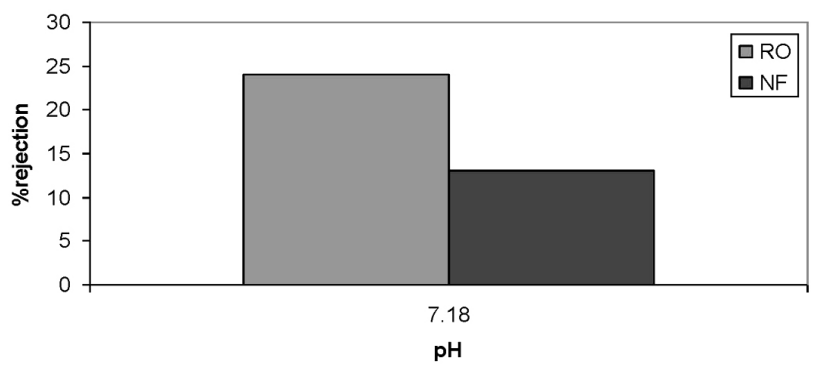

Figure 6: Effect of $\mathrm{pH}$ on removing sodium ions using $\mathrm{RO}$ and $\mathrm{NF}$ membranes

Slika 6: Vpliv pH na odstranitev ionov natrija, z uporabo RO in NF membran

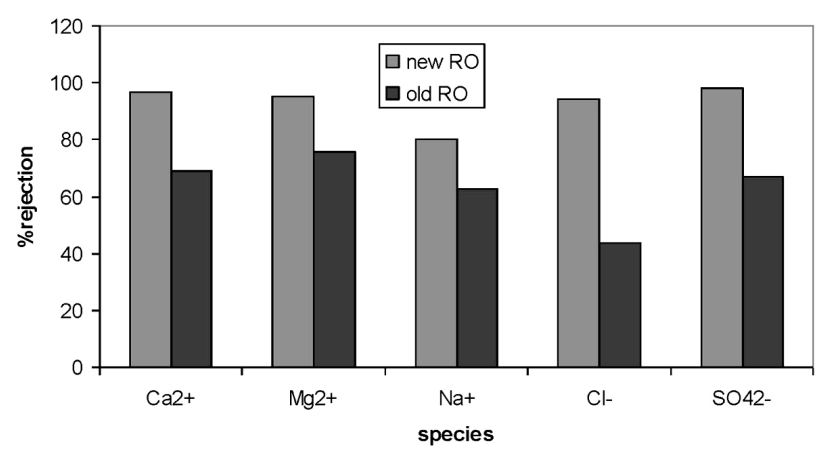

Figure 7: Comparison of the performance of RO membranes during 3 years of operation

Slika 7: Primerjava zmogljivosti RO-membran med triletnim obratovanjem

3 years. It was found that the rejection decreased for polyvalent cations and anions. This behavior was expected with the old membranes. On the other hand, the percent rejection of monovalent cations and anions by NF was not affected. For example, the percentage rejection of $\mathrm{Cl}^{-}$ion was $11.6 \%$, while after three years, the membrane rejection was $9.62 \%$. The rejection of $\mathrm{SO}_{4}^{-}$ions was $97.22 \%$ with the new membrane, while after 3 years the membrane rejection was $61.43 \%$. A strong rejection was observed for polyvalent cations and anions by $\mathrm{NF}^{46}$

Figure 9 and Table 1 show the percent decline of RO for the treatment of waste water containing cations and anions. It is clear that the decline in the performance of $\mathrm{RO}$ was higher during 3 years operation. This decline in performance could be attributed to fouling and biofouling on the surface of the membrane. In conclusion, this promising method, based on these results, suggests replacing the old membrane by a new product. Where the $\%$ decline of performance of membrane (decline \%) can be calculate as follows in Equation (2):

$$
\text { decline } \%=\frac{c-d}{c} \times 100
$$

$c$ - rejection of new membrane, $d$ - rejection of old membrane

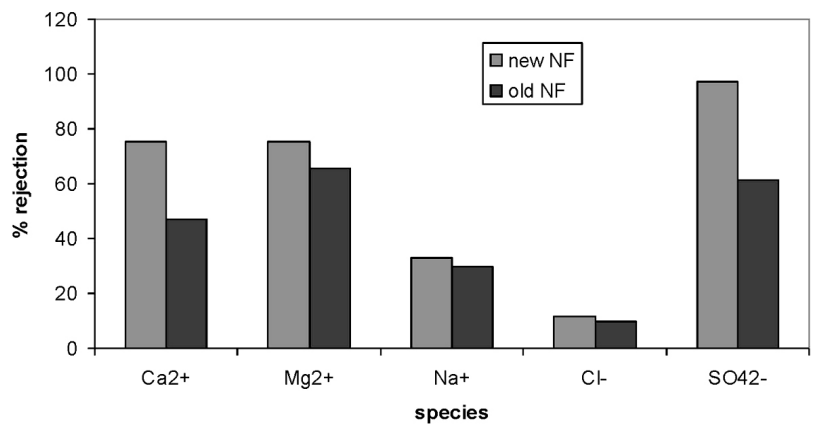

Figure 8: Comparison of the performance of NF membranes during 3 years operation

Slika 8: Primerjava zmogljivosti NF membrane med triletnim obratovanjem 
S. AL-JLIL: PERFORMANCE OF NANO-FILTRATION AND REVERSE OSMOSIS PROCESSES ...

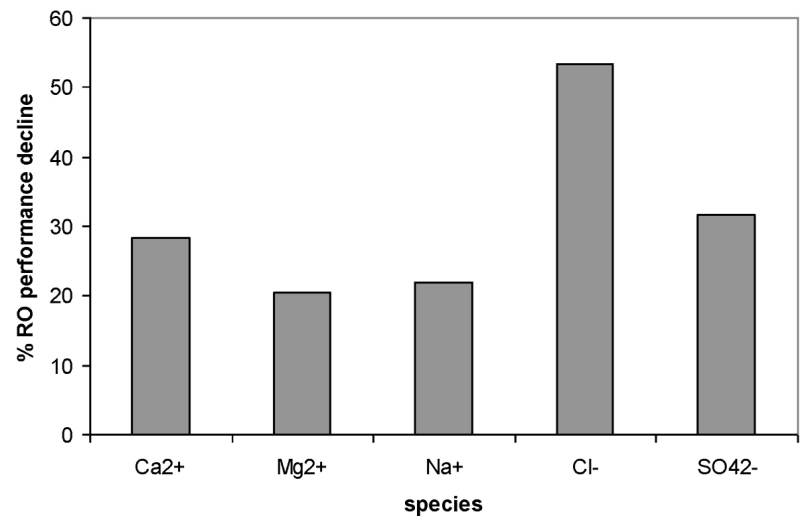

Figure 9: Percentage decline of the performance of RO during 3 years operation

Slika 9: Odstotek zmanjšanja zmogljivosti RO med triletnim obratovanjem

Table 1: Percentage decline of the performance of RO

Tabela 1: Odstotek zmanjšanja zmogljivosti RO

\begin{tabular}{|c|c|}
\hline Species & \% decline of performance of RO \\
\hline $\mathrm{Ca}^{2+}$ & 28.38 \\
\hline $\mathrm{Mg}^{2+}$ & 20.39 \\
\hline $\mathrm{Na}^{+}$ & 21.98 \\
\hline $\mathrm{Cl}^{-}$ & 53.45 \\
\hline $\mathrm{SO}^{2-}$ & 31.73 \\
\hline
\end{tabular}

Figure 10 and Table 2 show the percent decline in the performance of NF for the treatment of wastewater containing cations and anions. It is clear that the decline in the performance of NF was higher during 3 years operation, which might be due to fouling and biofouling on the surface of the membrane. The results of this investigation suggest that the old membrane should be replaced with the new product.

Table 2: Percentage decline of the performance of NF

Tabela 2: Odstotek padanja zmogljivosti pri NF

\begin{tabular}{|c|c|}
\hline Species & \% decline of performance of NF \\
\hline $\mathrm{Ca}^{2+}$ & 37.67 \\
\hline $\mathrm{Mg}^{2+}$ & 12.72 \\
\hline $\mathrm{Na}^{+}$ & 9.37 \\
\hline $\mathrm{Cl}^{-}$ & 16.97 \\
\hline $\mathrm{SO}^{2-}$ & 36.81 \\
\hline
\end{tabular}

\subsection{Factors affecting the decline performance of the membrane}

There are many factors that affect the performance of membranes, such as membrane fouling and biofouling, membrane degradation by oxidation and hydrolysis, mechanical damage, inorganic colloids, adsorbed organics, coagulants, silica scale and other inorganic scale and fouling with waste water. In general, biofouling and fouling are the major constraints that cause a decline in the performance of membranes. In order to find the possible reasons causing a decline in membrane performance, membrane autopsy was conducted to collect

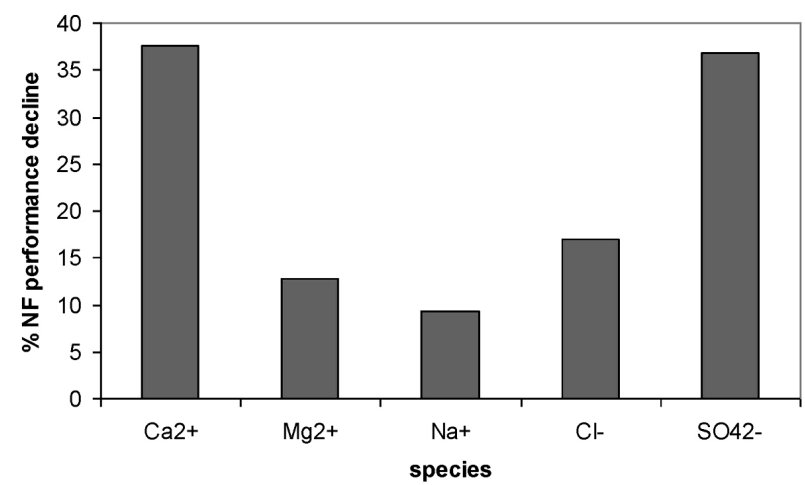

Figure 10: Percentage decline of the performance of NF during 3 years operation

Slika 10: Odstotek padanja zmogljivosti NF med triletnim obratovanjem

sheet membrane samples for examination by using energy-dispersive $\mathrm{x}$-ray to analyze the fouling deposit. Also, Fourier-transform infrared spectroscopy was used to identify the components of the deposition that deposit on the membrane. In addition, SEM can be used with the membrane samples to show the advanced fouling on the membrane surface

\subsection{Factors to control membrane fouling}

Many factors can be used to control the membrane fouling, these are:

1. Pretreatment for the water.

2. Membrane cleaning in the early stages of fouling.

3. Control of bacterial growth by depriving bacteria from nutrition by controlling the organic content in the feed water.

4. Efficient control of membrane fouling by proper sanitization of membrane system by using chlorination or UV.

\section{CONCLUSIONS}

Nano-filtration (NF) is very effective in removing polyvalent cations and anions such as $\mathrm{SO}_{4}^{-}$(where the percent rejection of $\mathrm{SO}_{4}^{-}$ions was $97.22 \%$ ). While the $\mathrm{RO}$ membrane is very effective in removing all ions, especially the monovalent cations and anions such as $\mathrm{Cl}^{-}$, where the percent rejection of $\mathrm{Cl}^{-}$ions was $94.4 \%$. The decline in the performance of RO and NF was very significant after 3 years of operation, attributed mainly to fouling and biofouling on the surface of the membrane. The study results suggested strongly to replace the old membranes with new ones to improve the system performance and efficiency for wastewater treatment on a cost-effective basis.

\subsection{Recommendations and suggestions}

1. Change the membrane for a new one. 
2. Observe the performance after fixing a new membrane and backwash after $10 \%$ of decline in performance.

3. Conduct training for the technicians in RO and NF systems maintenance, including the backwash and fouling problems.

4. Regular cleaning of the membrane to improve recovery of the membrane.

5. Conduct autopsy of the membrane to know the exact reason for the decline of performance.

6. Use an alternate membrane, such as a ceramic membrane.

\section{REFERENCES}

${ }^{1}$ M. Al-Shammiri, A. Al-Saffar, S. Bohamad, M. Ahmed, Waste water quality and reuse in irrigation in Kuwait using microfiltration technology in treatment, Desalination, 185 (2005) 1-3, 213-225, doi:10.1016/j.desal.2005.02.078

${ }^{2}$ P. S. Cartwright, Membranes separations technology for industrial effluent treatment, Desalination, 56 (1985), 17-35, doi:10.1016/ 0011-9164(85)85012-8

${ }^{3}$ P. S. Cartwright, Zero Discharge/Water Reuse - The opportunities for membrane technologies in pollution control, Desalination, 83 (1991) 225, 225-241, doi:10.1016/0011-9164(91)85097-E

${ }^{4}$ C. S. Slater, R. C. Ahlert, C. G. Uchrin, Applications of reverse osmosis to complex industrial wastewater treatment, Desalination, 48 (1983) 2, 171-187, doi:10.1016/0011-9164(83)80015-0

${ }^{5}$ A. H. Ghabris, M. Abdel-Jawad, G. S. Aly, Municipal wastewater renovation by reverse osmosis state of the art, Desalination, 75 (1989), 213-240 , doi:10.1016/0011-9164(89)85015-5

${ }^{6}$ T. Eisenberg, E. Middlebrooks, Reverse osmosis treatment of drinking water, (1986), 1-271, doi:10.1016/B978-0-250-406173.50004-4

${ }^{7}$ E. Chian, W. Bruce, H. Fang, Removal of pesticides by reverse osmosis, Environmental Science and Technology, 364 (1975) 9 , 52-59, doi:10.1021/es60099a009

${ }^{8}$ H. Odegaard, S. Koottatep, Removal of humic substances from natural waters by reverse osmosis, Water Research, 16 (1982) 5, 613-620, doi:10.1016/0043-1354(82)90082-3

${ }^{9}$ T. Clair, J. Kramer, M. Sydo, D. Eaton, Concentration of aquatic dissolved organic matter by reverse osmosis, Water Research, 25 (1991) 9, 1033-1037, doi:10.1016/0043-1354(91)90196-w

${ }^{10}$ T. Sorg, R. Forbes, D. Chambers, Removal of radium-226 from sarasota county, fla., drinking water by reverse osmosis, Journal AWWA, 72, (1980) 4, 230-237, doi: JAW-0003802 2

${ }^{11}$ J. Baier, B. Lykins, C. Fronk, S. Kramer, Using reverse osmosis to remove agricultural chemicals from groundwater, Journal AWWA, 79 (1987) 8, 55-60, doi: JAW-0021235

${ }^{12}$ J. Taylor, D. Thompson, J. Carswell, Applying membrane processes to groundwater sources for Trihalomethane precursors, Journal AWWA, 79 (1987) 8, 72-82 doi: JAW-0021238

${ }^{13}$ L. Tan, R. Sudak, Removing color from a groundwater source, Journal AWWA, 84 (1992) 1, 79-87, doi:JAW-0031493

${ }^{14} \mathrm{~J}$. Cruver, Waste-treatment applications of reverse osmosis, Transactions ASME, 97 (1976) 1, 246-251, doi:10.1115/1. 3438546

${ }^{15}$ H. Fang, E. Chian, Reverse osmosis separation of polar organic compounds in aqueous solution, Environmental Science \& Technology, 10 (1976) 4, 364-369, doi:10.1021/es60115a011

${ }^{16} \mathrm{H}$. Tsuge, R. Mori, Reclamation of municipal sewage by reverse osmosis, Desalination, 23 (1977) 1, 123-132, doi:10.1016/S00119164(00)82515-1
${ }^{17}$ N. Richardson, D. Argo, Orange county's 5 MGD reverse osmosis plant, Desalination, 23 (1977) 1, 563-573, doi:10.1016/ S0011-9164(00)82555-2

${ }^{18}$ P. Allen, G. Elser, They said it couldn't be done-the orange County, California experience, Desalination, 30 (1979) 1, 23-38, doi:10.1016/S0011-9164(00)88430-1

${ }^{19}$ I. Nusbaum, D. Argo, Design, operation, and maintenance of a 5-mgd wastewater reclamation reverse osmosis plant. in Synthetic Membrane Processes: Fundamentals and Water Applications, Academic Press, Orlando, FL, (1984), 377-436, doi:10.1016/B9780-12-085480-6.50016-5

${ }^{20}$ E. Csefalvay, P. M. Imre, P. Mizsey , Applicability of nanofiltration and reverse osmosis for the treatment of wastewater of different origin, Central European Journal of Chemistry, 6 (2008) 2, 277-283, doi:10.2478/s11532-008-0026-3

${ }^{21}$ M. Gholami, R. Mirzaej, R. R. Kalantary, A. Sabzali, F. Gatei, Performance evaluation of reverse osmosis technology for selected antibiotics removal from synthetic pharmaceutical wastewater, Iranian J Environ Health Sci. Eng, 9 (2012) 1, 9-19, doi:10.1186/ 1735-2746-9-19

${ }^{22}$ E. Sahar, I. David, Y. Gelman, H. Chikurel, A. Aharoni, R. Messalem, A. Brenner, The use of RO to remove emerging micropollutants following CAS/UF or MBR treatment of municipal wastewater, Desalination, 273 (2011), 142-147, doi:10.1016/j.desal. 2010.11.004

${ }^{23}$ P. Eriksson, Nanofiltration extends the range of membrane filtration, Environmental Progress, 7 (1988) 1, 58-62, doi:10.1002/ep. 3300070116

${ }^{24}$ J. Cadotte, Forester, R. Kim, M. Petersen, R. T. Stocker, Nanofiltration membranes broaden the use of membrane separation technology, Desalination, 70 (1988) 1-3, 77-88, doi:10.1016/00119164(88)85045-8

${ }^{25} \mathrm{~W}$. Conlon, Pilot field test data for prototype ultra low pressure reverse osmosis elements, Desalination, 56 (1985), 203-226, doi:10.1016/0011-9164(85)85026-8

${ }^{26}$ B. Watson, C. Homburg, Low-energy membrane nanofiltration for removal of color, organics and hardness from drinking water supplies, Desalination, 72 (1989) 1/2, 11-22, doi:10.1016/00119164(89)80024-4

${ }^{27}$ W. Conlon, C. Homburg, B. Watson, C. Kiefer, Membrane softening: the concept and its application to municipal water supply, Desalination, 78 (1990) 2, 157-175, doi:10.1016/0011-9164(90) 80040-1

${ }^{28}$ P. Lange, P. Laverty, E. Edwards, I. Watson, THM precursor removal and softening - ft. myers 12 mgd ro membrane plant, Florida USA, Desalination, 76 (1989), 39-52, doi:10.1016/0011-9164(89)87037-7

${ }^{29}$ G. Amy, B. Alleman, C. Cluff, Removal of dissolved organic matter by nanofiltration, Journal of Environmental Engineering, 116 (1990) 1, 200-205, doi:10.1061/(ASCE)0733-9372

${ }^{30} \mathrm{~S}$. Duranceau, J. Taylor, L. Mulford, SOC Removal in a membrane softening process, Journal AWWA, 84 (1992) 1, 68-78

${ }^{31}$ A. Bindoff, C. Davies, C. Kerr, C. Buckley, The nanofiltration and reuse of effluent from the caustic extraction stage of wood pulping, Desalination, 67 (1987), 455-465, doi:10.1016/0011-9164(87) 90262-1

${ }^{32}$ K. Ikeda, T. Nakano, H. Ito, T. Kubota, S. Yamamoto, New composite charged reverse osmosis membrane, Desalination, 68 (1988) 2 , 109-119, doi:10.1016/0011-9164(88)80048-1

${ }^{33}$ M. Afonso, V. Geraldes, M. Rosa, M. De Pinho, Nanofiltration removal of chlorinated organic compounds from alkaline bleaching effluents in a pulp and paper plant, Water Research, 26 (1992) 12, 1639-1643, doi:10.1016/0043-1354(92)90163-X

${ }^{34}$ M. Simpson, C. Kerr, C. Buckley, The effect of ph on the nanofiltration of the carbonate system in solution, Desalination, 64 (1987), 305-319, doi:10.1016/0011-9164(87)90104-4

${ }^{35} \mathrm{~S}$. Gaeta, U. Fedele, Recovery of water and auxiliary chemicals from effluents of textile dye houses, Institution of Chemical Engineers Symposium Series, 83 (1991) 1/3, 183-194, doi:10.1016/00119164(91)85094-B 


\section{MATERIALI IN TEHNOLOGIJE/MATERIALS AND TECHNOLOGY (1967-2017) - 50 LET/50 YEARS}

\section{S. AL-JLIL: PERFORMANCE OF NANO-FILTRATION AND REVERSE OSMOSIS PROCESSES ...}

${ }^{36}$ M. Perry, C. Linder, Intermediate reverse osmosis ultrafiltration (ROUF) membranes for concentration and desalting of low molecular weight organic solutes, Desalination, 71 (1989) 3, 233-245, doi:10.1016/0011-9164(89)85026-X

${ }^{37}$ D. Bhattacharyya, R. Adams, M. Williams, Separation of selected organics and inorganic solutes by low pressure reverse osmosis membranes, in biological and synthetic membranes, D. Butterfield, ed., Alan R. Liss, New York. 292 (1989) 1-2, 153-67, doi:10.1002/ pi.4980230130

${ }^{38}$ M. Williams, R. Deshmukh, D. Bhattacharyya, Separation of hazardous organics by reverse osmosis membranes, Environmental Progress, 9 (1990) 2, 118-125, doi: 10.1002/ep.670090220

${ }^{39}$ R. Rautenbach, A. Gröschl, Separation potential of nanofiltration membranes, Desalination, 77 (1990), 73-84, doi:10.1016/00119164(90)85021-2

${ }^{40}$ M. Chu, C. Tung, M. Shieh, A study on triple-membrane-separator (TMS) process to treat aqueous effluents containing uranium, Separation Science and Technology, 25 (1990) 13-15, 1339-1348, doi:10.1080/01496399008050395

${ }^{41}$ C. Dyke, C. Bartels, Removal of organics from offshore produced waters using nanofiltration membrane technology, Environmental Progress, 9 (1990) 3, 183-186, doi:10.1002/ep.670090320
${ }^{42}$ L. H. Andrade, F. D. S. Mendes, J. C. Espindola, M. C. S. Amaral Reuse of dairy wastewater treated by membrane bioreactor and nanofiltration: technical and economic feasibility, Braz. J. Chem. Eng., 32 (2015) 3, 735-747, doi:10.1590/0104-6632.20150323s00003133

${ }^{43}$ E. L. Subtil, J. C. Mierzwa, I Hespanhol, Comparison between a conventional membrane bioreactor (C-MBR) and a biofilm membrane bioreactor (BF-MBR) for domestic wastewater treatment, Braz. J. Chem. Eng.,31 (2014) 3, 683-691, doi:10.1590/01046632.20140313s00002890

${ }^{44}$ F. A. Riera, A. Suárez, C. Muro, Nanofiltration of UHT flash cooler condensates from a dairy factory: Characterisation and water reuse potential, Desalination, 309 (2013), 52-63, doi:10.1016/j.desal. 2012.09.016

${ }^{45}$ L. H. Andrade, G. E. Motta, M. C. S. Amaral, Treatment of dairy wastewater with a membrane bioreactor. Braz. J. Chem. Eng., 30 (2013) 4,759-770, doi:10.1590/S0104-66322013000400008

${ }^{46}$ M. G. Khedr, Nanofiltration and low energy reverse osmosis for rejection of radioactive isotopes and heavy metal cations from drinking water sources, Desalination and Water Treatment, 2 (2009), 342-350, doi:10.5004/dwt.2009.333

${ }^{47}$ M. Einar, S. Bjorn, Concentration polarization and fouling, Desalination, 35 (1980), 59-103, doi:10.1016/s0011-9164(00)88604-x 